\title{
Water Cycle Impacts of Residential Water Demand in an Aquifer-based Municipal Water Supply and Treatment System: Model Development, Implementation, and Case Studies
}

\author{
Shirley Morque ${ }^{1}$, Mansour Sodagari ${ }^{1}$, Robert Ries ${ }^{1}$ \\ ${ }^{1}$ M.E. Rinker, Sr., School of Construction Management \\ University of Florida, Gainesville, FL, USA
}

\begin{abstract}
The hydrological cycle is significantly impacted when natural land cover is converted to urban land use. Pristine land cover and urban development have very different infiltration, evapotranspiration, and runoff rates, affecting streams and groundwater recharge. Rapid urbanization globally has resulted in the transformation and modification of natural land cover such as forested and grassland to industrial, commercial and residential developments. In addition, urban areas are served by potable and waste water systems that supply, treat, and convey water from source water through infrastructure to treatment and disposition. Shifting water partitioning through impervious surface change and the introduction and mobilization of water into urban environments alters the water cycle, affects streams and aquifers, and impacts ecological systems. The research has developed a water balance model framework to analyze the effect of the built environment on water partitioning and the consequential impact on the environment. Results from the application of the water balance model on two communities in Alachua county, Florida indicated that hydrological factors such as infiltration and runoff increase significantly when land is transformed from an undeveloped to a developed state with increased imperviousness. Also affected are water withdrawal volumes, irrigation water use, and how extracted water is treated and disposed. Approximately 50\% of the difference between undeveloped and developed conditions were alleviated with the use of effective stormwater management practices. The study concluded that significant changes are observed when land is altered from its natural state and measures to maintain natural land cover water flow characteristics in urban areas are necessary to control this change.
\end{abstract}

\section{Introduction}

Efforts towards addressing global sustainability issues mostly dwell on energy conservation and efficiency, and global warming or carbon emission control. Historically, water scarcity has not been a concern, possibly due to the notion that water is an abundant resource. The earth's surface is about $80 \%$ water (United SGS, 2016). Water is core to human existence and therefore critical for sustainable development. Water affects human and ecosystem functioning, environmental health, economic and social wellbeing, and impacts poverty reduction and energy security (Kemper \& Sadoff, 2006, Connor, 2015).
Water is available on earth as freshwater (surface water and groundwater), and saline water. Of the earth's abundant water reserve, the saline water represents $97 \%$, leaving 3\% as fresh water resources. The majority of the fresh water available is in glaciers or deep inaccessible areas in the ground. This then leaves only a small fraction of water available for human consumption (Gleick \& Palaniappan, 2010; (United States Geological Survey) USGS, 2016). Therefore, water, as any natural resource, needs to be protected and well managed in order to ensure its continuous availability to meet future demands. Hence water resource availability is an important environmental and sustainable concern.

Water for potable uses is typically available as either surface water or aquifers. When water is taken or withdrawn from its natural location, it often does not return to its original source. In most instances water is considered "lost", that is, water not returned to the source from which it was withdrawn, causing a deficit at the source. This is often referred to as consumptive water use, although the water loss is usually directed to other locations in various forms, including the atmosphere (Chabbra. 2011). Thus, the water consumed is not necessarily lost but relocated and transformed. Water may be replenished eventually, but in many instances, the rate of return or replenishment is less than the withdrawal rate. That is to say more water is being withdrawn from a source than is being replenished to that source through the hydrologic cycle. The hydrological cycle functions through evaporation, rainfall or precipitation, surface runoff and infiltration, which enables water to progress through the environment as solid, liquid, or gas. Continuous withdrawal of water from its natural location and state will eventually lead to a reduction in water availability from that source over time. The stock of water available globally differs from region to region and is affected by various factors including but not limited to population, usage rate and management, wastewater treatment, and governance. As such if water is withdrawn from one place and ends up in another region, it reduces the water availability in the region from which it was withdrawn. Therefore, on a regional basis, depending on the volume of water available and policies regulating water distribution, management, quality, maintenance and human and industrial pollution, the issue of future water availability and water scarcity can become a major concern. 
Water can also be a renewable or a non-renewable resource depending on its flow and stock. Water flow is considered renewable when the rate of flow from one stock to another has no effect on its flow or natural recharge rate. Water availability becomes an issue when the rate of withdrawal and transfer through human intervention is not directly proportional to the rate at which it is being replenished or recharged. On the other hand, when the stock of water for use is limited in a particular region, water is considered non-renewable and becomes a challenge as water withdrawn from this regional stock will reduce the water available in that particular region and hence making water unavailable in that stock (Gleick \& Palaniappan. 2010; Chabbra. 2011). Therefore, although water is available and in abundance globally, there is still the need to critically assess water usage, distribution and management and also examine how human development affects water availability (United Nations World Water Development Report, 2015).

\section{Problem Statement and Relevance}

As long as global population continues to increase, the need for development to meet the needs of the growing population will continue to be a priority worldwide. Increased urbanization has resulted in more impervious surfaces. With the growing increase in urban settlement, natural vegetated lands have been converted to constructed or built surfaces (Shuster et al., 2005; Redfern et al., 2016). Providing housing, transportation and other infrastructure results in land use or land cover change. The built environment includes buildings and open areas around them such as landscaping (Chabbra, 2011). Water flow, water distribution, water quality and the hydrological cycle are impacted by development. The built environment alters the natural pattern of the hydrological cycle and water resources causing irregularities in water supply and can diminish the available stock. This can be a threat to future water availability in the long term if not addressed.

In 2002, the United States Environmental Protection Agency (USEPA) reported that 52\% of Ohio's rivers assessed were classified as impaired. USEPA attributed 9,167 impaired river miles as a probable result of development. This included construction activities such as unspecified urban storm water; land clearing for development and redevelopment; destabilization of stream banks due to development; removal of riparian vegetation; construction of sewer lines; and road, bridge, and highway construction (Houser \& Pruess, 2009; USEPA, 2012). The USEPA further listed hydrologic modification, habitat modification, agriculture, and urban runoff and storm sewers as leading sources of water resource pollution and alteration. USEPA also emphasized that this 39\% impairment was an increase over the 1998 inventory, which reported 35\% (Houser \& Pruess, 2009; USEPA, 2002).

Florida, in general, presents fairly unique climate and water circumstances due to its dependency on groundwater for the majority of potable water use in the state. The aquifer is productive but also sensitive to withdrawals and infiltration in parts of the state making withdrawal and development patterns a challenge depending on the location.

This study will contribute the following towards improving the relationship of buildings and their surroundings relative to water to help achieve a sustainable environment:

- $\quad$ Provide data in the form of water balance model to help evaluate water partitioning in the environment and its effect on water resources.

- $\quad$ Provide data to estimate water input and water output in a building.

- $\quad$ Establish the relationship between water demand and supply of water in buildings.

- $\quad$ Establish the role increased impervious surfaces play in water partitioning, and water use in buildings.

- $\quad$ Evaluate the relationship between water use in a pristine environment and in a developed environment.

The data from this study can be used by developers, designers, construction professionals, building owners and residents to help select best practices in designing, construction of buildings and the efficient use of water in buildings.

\section{Case Study Areas (Town of Tioga and Oakmont)}

The Town of Tioga and Oakmont are two residential communities in Alachua County, Florida (see Figure 2). The two communities are generally similar except one community uses reclaimed water for landscape irrigation and the other uses potable water for irrigation.

The Town of Tioga has been developed over the past thirty years. Properties in this neighborhood were built beginning in 1986. The development has 18 different phases, with up to 23 phases in the future. Total land cover is 279 acres, and the total number of residential units planned is 537. The Town of Tioga water use is primarily served by GRU's Murphree Wellfield and Water Treatment plant, which extracts water from the upper Floridan aquifer. Potable water is used for both domestic uses and irrigation in the Town of Tioga.
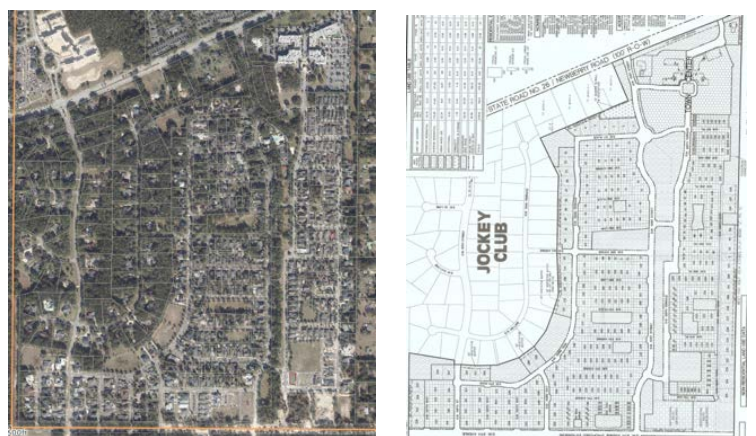

Figure 2: Tioga Town Area View and zoning map

Source Alachua County Growth Management

The Oakmont neighborhood is a relatively new community (see Figure 3). The first phase of Oakmont started in 2014. Total land cover is 556 acres, and the total number of residential units planned is 999. The 
development is planned to be completed by 2024 . Oakmont's potable water use is also primarily served by Gainesville Regional Utility (GRU's) Murphree Wellfield and the upper Floridan aquifer. Potable water is used for domestic uses in Oakmont. However, Oakmont has access to reclaimed water from the Kanapaha Water Reclamation Facility for landscape irrigation. The reclaimed water offsets potable water extracted from the upper Floridan aquifer for irrigation.
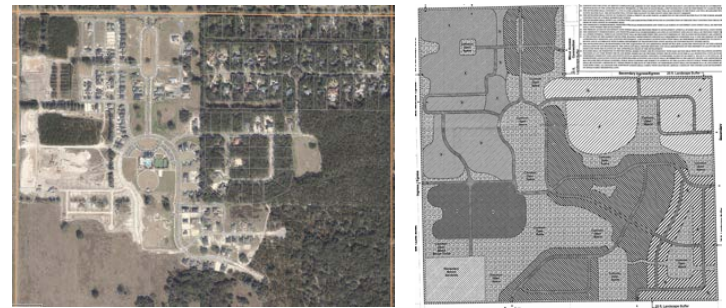

Figure 3: Oakmont Area View and zoning map Source Alachua County Growth Management

\section{Methods}

In order to assess the impact of the built environment on water resources, a quantitative approach was used. The model uses a water balance framework. A water balance model is a straightforward representation of the connections and interfaces between climate and site characteristics using climate data and available parameters that describe the hydrologic performance of land areas and regions at several geographical scales. (Grimmond et al., 1986; Mitchell et al., 2008; Chhabra, 2011; Charalambous et al., 2012; Wu et al., 2015; Erban et al., 2018).

The water balance model was used to evaluate a case study of the pre-development and development states of communities in terms of water withdrawal, runoff, evapotranspiration, and infiltration volumes (see Figure 1 ). The water volumes were calculated and compared for the developed and undeveloped conditions, with understanding that the closer the developed state was to the baseline undeveloped state, the better. Ultimately, the aquifer's productivity will depend on withdrawal, recharge, and infiltration rates.

The model framework can be used to establish the differences between undeveloped and developed conditions. The model results will establish the type and intensity of the deviation of water partitioning brought about by the built environment. The framework can also be used to model and test alternative design options.

The model framework tracks high-level variables withdrawal, runoff, evapotranspiration (ET), and infiltration - at the undeveloped state and in various development stages as the land transitions from pristine with no water withdrawals to increasingly impervious with increasing water withdrawals.

Overall runoff, evapotranspiration (ET), and infiltration is obtained from the water balance model. The model results estimate the partitioning of water in the environment given the natural (precipitation) and water infrastructure (water withdrawal and wastewater treatment) inputs.
Landscape characteristics, climate, precipitation, water end uses at the parcel level, infrastructure, and disposition of water after waste water treatment determine the partitioning into evapotranspiration, runoff, and infiltration. Understanding and modelling the water distribution, supply chain, and treatment processes is necessary to partition the water withdrawal and waste water treatment end uses and dispositions.

In the case study, US Environmental Protection Agency (EPA) water cycle partitioning parameters and local climatic conditions pertaining to the case study areas were used to partition precipitation into runoff, evapotranspiration, and infiltration at the parcel level (FSU, 2000; EPA, 2018; Rainmaster, 2018; Weather Underground, 2018). Runoff was calculated using the curve number method (Harper \& Baker, 2007) and evapotranspiration was calculated using the Turc method (Turc, 1961; Dryer, 2009). Average water partitioning given the percent imperviousness of the landscape has been developed by the EPA (Harper \& Baker, 2007, California Water \& Land Use Partnership. 2018). Both the partitioning from site-specific local climatic conditions and the EPA water partitioning coefficients were used to describe the performance of on-site storm water management. Storm water management best practices are measures that manage runoff and improve water quality. Examples include retention areas, vegetated filter strips, rain barrels, green roofs, permeable pavement, bioretention, swales, curb and gutter removal, constructed wetlands, and sand and organic filters (EPA, 2019). Runoff, evapotranspiration, and infiltration related to storm water management structures are modeled and contribute to the total partitioning.

Water used at the parcel level was categorized as potable water and reclaimed water and the case study included landscape irrigation from potable and reclaimed water. Reclaimed water refers to waste water generated from potable water use that has been treated for reuse. Reclaimed water is typically used for irrigation.

The same partitioning parameters and climatic conditions were also applied to potable and reclaimed water applied to parcels as irrigation that partitions into runoff, evapotranspiration, and infiltration. The same approach was used to calculate parameters for undeveloped land in its natural state. Water partitioning was considered at all waste water treatment end use and disposition types. Waste water injected into wells after treatment is considered infiltration. See Table 1 for a summary of the model variables.

The resulting model holistically characterizes water withdrawal, distribution and recharge under given climatic conditions, how changes occur as water withdrawal and imperviousness increases, and how the hydrology or water cycle is impacted. The results from this study help identify best management practices for improving recharge or enhancing infiltration and sustaining the productivity of water sources to meet future needs. 


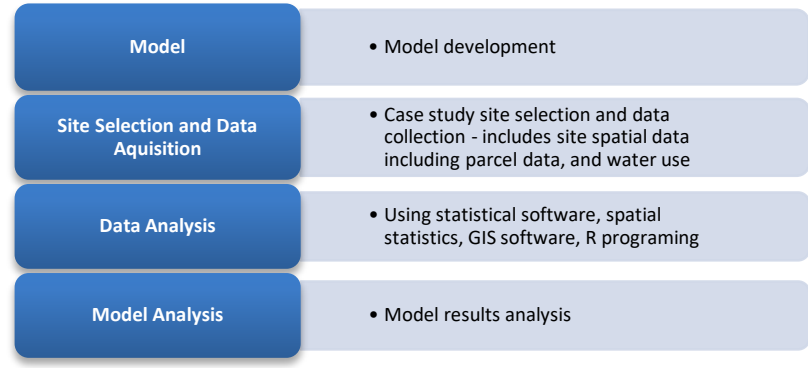

Figure 1: Research and model development flowchart

\section{Data Sources}

Water withdrawal and consumption data was acquired from the water utility, namely, Gainesville Regional Utility (GRU). Site information was obtained from the local governmental agency, the Alachua County Property office. Site information used in the analysis includes zoning master plans and Geographical Information System (GIS) files, including parcels in Alachua County. Site information such as parcel size, building footprint, and year built were obtained using GIS.

\section{GRU Water Treatment and Distribution Processes}

The Floridan aquifer is the main source for the majority of public water systems in Florida. The Floridan underlies an area of about 100,000 square miles (Johnston \& Busch, 1988). Although the Floridan contains both fresh and brackish water, in most areas it is potable and requires little treatment before use. In 2000, approximately 3,135 million gallons per day was withdrawn from Floridan aquifer in Florida (Marella, 2004).

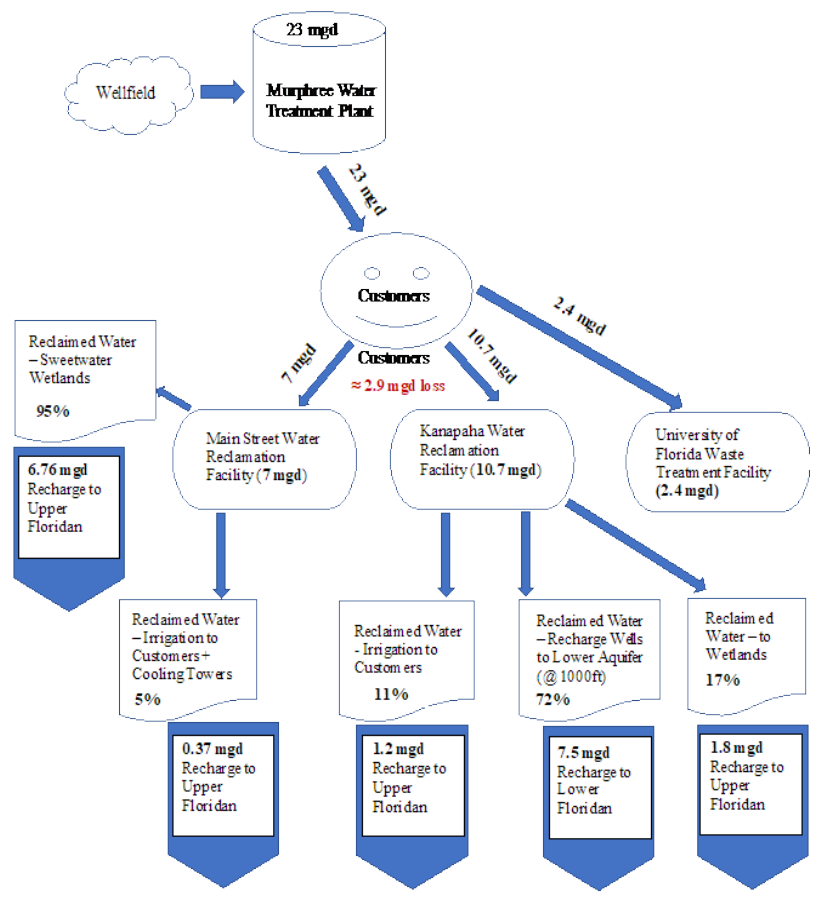

Figure 4: Overall GRU Water Withdrawal, Distribution and Supply Flowchart
GRU's process starts with water withdrawn from the aquifer at the Murphree Wellfield, treated at the Murphree Water Treatment plant, and distributed through a potable water piping network to homes and other commercial and institutional facilities. Potable water is used in homes in the GRU service area for both domestic use and irrigation. Waste water is generated, and then conveyed to waste water treatment plants through a piping network. A water distribution loss factor of $6.4 \%$ was estimated from GRU data and represents water loss through the distribution supply chain. The loss was assumed to result in groundwater infiltration.

GRU operates two waste water treatment plants, both of which use extensive treatment that generates high quality reclaimed water. The Oakmont community is connected to GRU's Kanapaha Water Reclamation Facility, which treats wastewater to drinking water quality standards for re-use. The facility produces an average of 10.7 million US gallons of reclaimed water per day. The majority of the reclaimed water (72\%) is deep well injected into the lower Floridan aquifer, which is separated by a clay confining layer from the upper Floridan in this area of Florida. Reclaimed water for irrigation is distributed through a reclaimed water piping network. Irrigation end uses represent $11 \%$ of the reclaimed water flow. The remainder, $17 \%$, is discharged to surface wetlands, including an adjoining botanical garden. See Figure 4 for an overall view of GRU water withdrawal and treatment flows and processes and Figure 5 for a process diagram of the natural and GRU processes and flows.

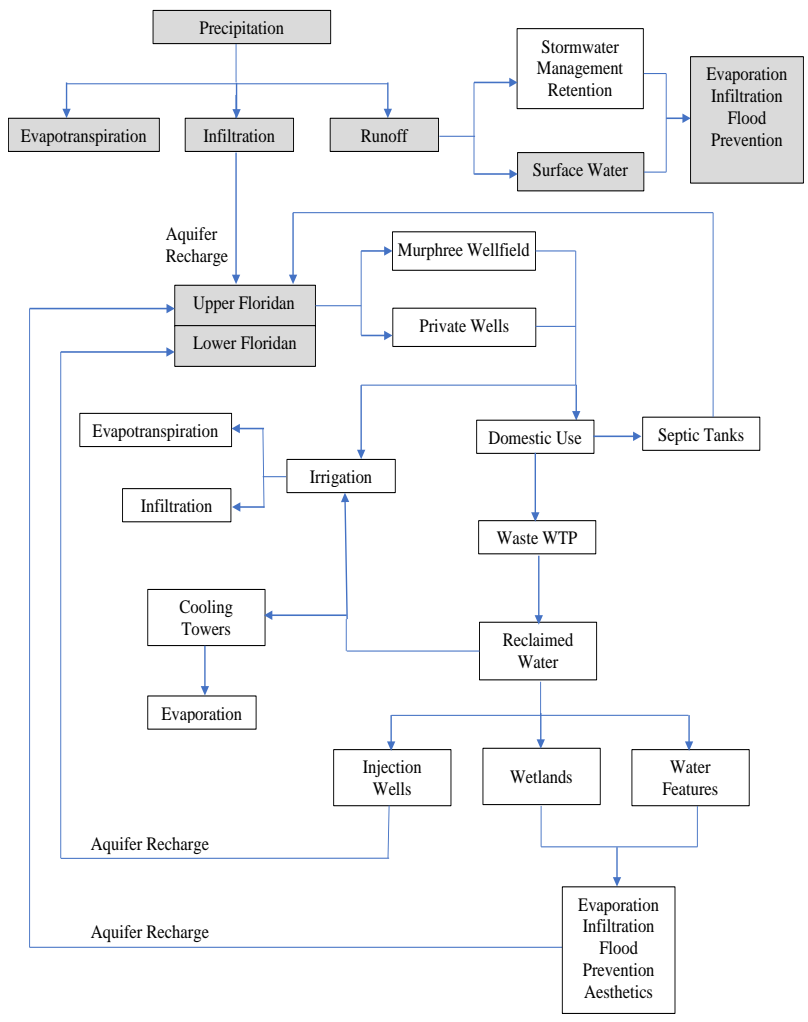

Figure 5: Process Diagram of Water in the Environment: Developed Water Supply and Treatment Processes shown in White; Pre-development Processes shown in Gray 


\section{Results}

Four scenarios were examined in this study, namely, the Town of Tioga and Oakmont communities with and without storm water management structures on site. Results discussed here are the model outputs at three different geographic scales - all parcels in the community, an average large parcel, and an average small parcel. The partitioning parameters are compared at the three scales in four scenarios.

Results from the case study showed that the majority of water inflow volume to the sites in these cases is from precipitation. Therefore, hydrologic partitioning volumes are primarily impacted by precipitation. However, there is a significant impact from water withdrawals at the parcel level.

Compared to the undeveloped state, infiltration and runoff are greater in both the Town of Tioga and Oakmont cases in all scenarios. This is caused by increased impervious surface area, water withdrawals and disposition after waste water treatment, and additional water applied to the site as irrigation.

Storm water management structures reduce runoff by more than $50 \%$. The water directed to storm water management structures is also partitioned into runoff, evapotranspiration, and infiltration thereby reducing total runoff and increasing evapotranspiration and infiltration. Smaller parcels presented high impervious area percentages compared to larger parcels and as such had the highest runoff rate per square foot in all four scenarios. Under storm water management scenarios, small parcels exhibited the highest runoff reduction compared to the without storm water management case. This result reinforces the importance of parcel- or community-scale storm water management structures that are designed to appropriately respond to local climatic and water conditions. The results also show that although the built environment changes hydrological partitioning, decreasing runoff and increasing infiltration with storm water management structures can potentially increase aquifer recharge. For example, the GRU injection wells in this particular study significantly increase aquifer recharge.

Availability of reclaimed water increases irrigation intensity in both large and small parcels in this case study. Irrigation water volume per square foot is greater in Oakmont where lower cost reclaimed water is available compared to Town of Tioga, which is served only by higher cost potable water for irrigation.

The use of reclaimed water in Oakmont reduced the intensity of potable water used on site compared to Town of Tioga. This ultimately reduces the volume of water withdrawn from the aquifer.

Water withdrawal from aquifer adds to the overall water inflow to site increasing inflow in the developed state compared to the undeveloped state. This affects the overall water balance partitioning on site and due to high evapotranspiration and runoff rates, not all inflows end up as aquifer recharge, not even when storm water management structures are in place.

\section{Validation}

The water balance model has not yet been validated but can be validated using empirical data. However, the model uses components that have been independently validated. Individual hydrological model components such as the curve number method for runoff (USDA, 1986; Ponce \& Hawkins, 1996; Silveira et al. 2000; Chatterjee et al. 2001; Harper \& Baker, 2007; Hawkins et al. 2002; Dile et al. 2016) and the Turc method for evapotranspiration (Turc, 1961; Lu et al. 2005; Salazar et al. 2006; Bios et al. 2008; Trajkovic \& Kolakovic 2009) have been validated. Infiltration, on the other hand, is derived from the water balance including runoff, evapotranspiration, and precipitation and considering the various water disposition stages and stormwater facilities.

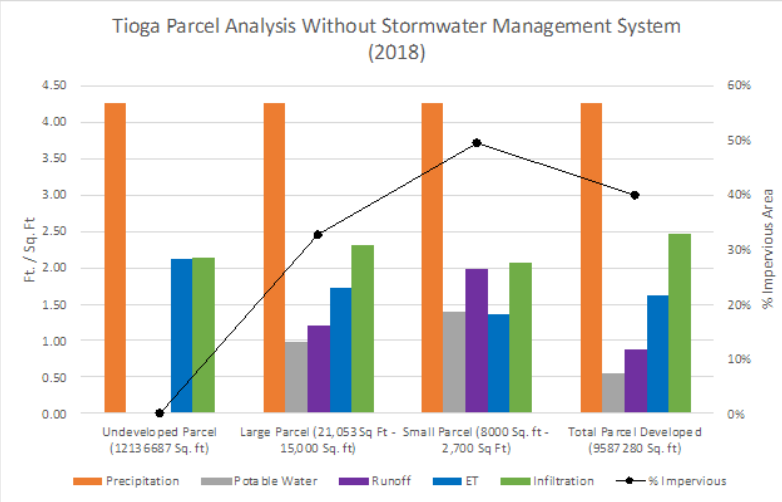

Figure 6: 2018 Water Partitioning Analysis without Storm water Management System, Town of Tioga

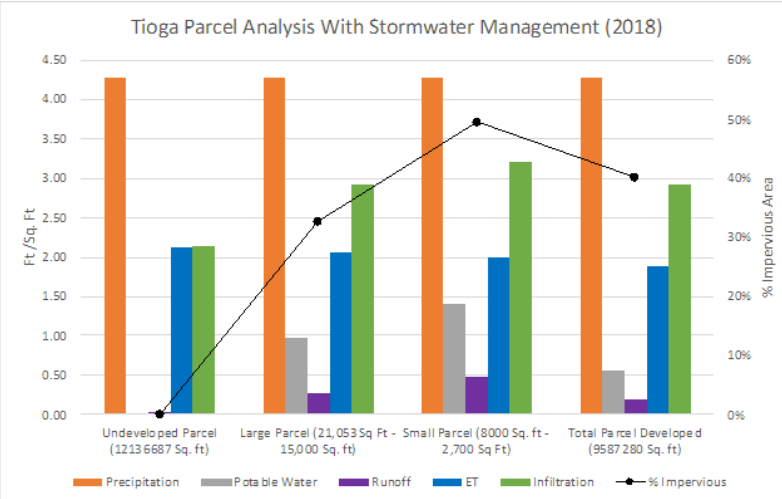

Figure 7: 2018 Water Partitioning Analysis with Storm water Management System, Town of Tioga

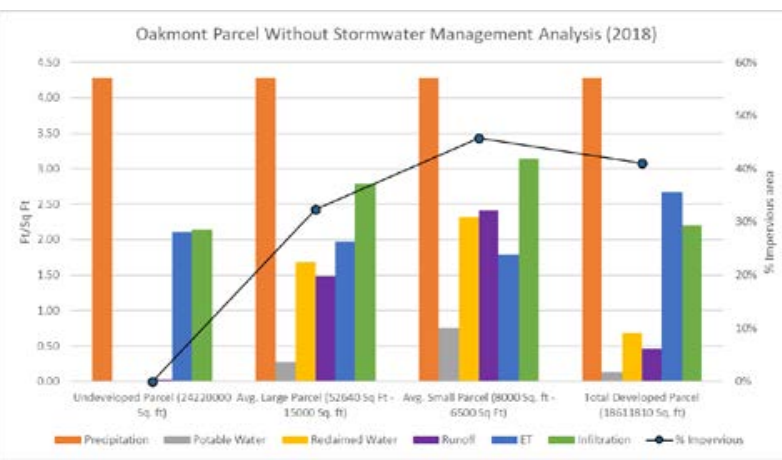

Figure 8: 2018 Water Partitioning Analysis without Storm water Management System, Oakmont 


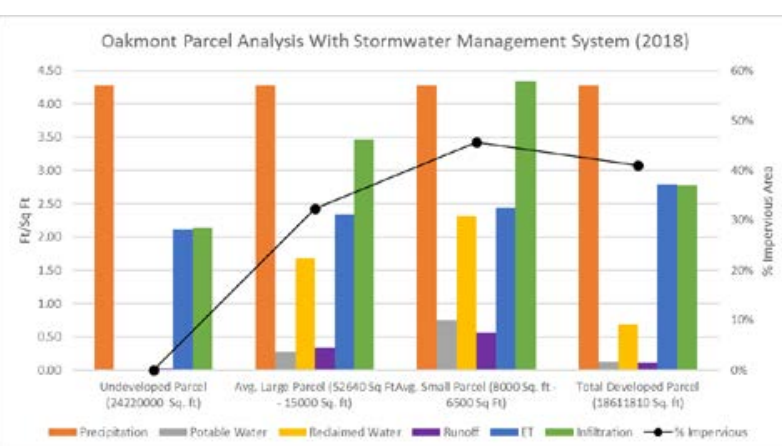

Figure 9: 2018 Water Partitioning Analysis with Storm water Management System, Oakmont

\section{Conclusion}

In conclusion, increased imperviousness and water withdrawal as a result urbanization results in changes to the water cycle compared to the natural or undeveloped state. The model results analysis clearly shows the alteration to the water cycle from pre-development to developed conditions. Development causes a high runoff rate from parcels. However, by implementing appropriate functional storm water management structures, the total runoff from a developed site as a whole can be addressed and greatly ameliorated. Overall, evapotranspiration and infiltration volumes are also increased as a result of increased water withdrawal, irrigation, and impervious land cover. In achieving water sustainability in groundwater-dominant regions, measures to increase aquifer recharge and reduce aquifer withdrawal are needed. The design of Low Impact Development (LID) technologies need to be investigated to focus on increasing infiltration and aquifer recharge. LID approaches need to be introduced in existing urban areas as well as new development.

LID must complement and augment flood control measures to prevent flooding in heavy, extended rainfall events. It is also recommended that the use of reclaimed water on site will be encouraged as the irrigation end use typically represents the greatest volume of water withdrawal. Although legitimate concerns remain for treated waste water reuse, opportunities for using reclaimed water for irrigation should also be studied and implemented regionally if possible. In addition, the use of reclaimed water for non-potable domestic use should also be studied and considered. Overall, detailed research and analysis is needed to determine the best measures and best practices for aquifer recharge and withdrawal. Research is needed to establish a baseline and set targets against which aquifer recharge and withdrawal can be measured to ensure successful long-term water resource management. This model may be applicable to determine baselines and targets and whether or not recharge and withdrawal targets are being achieved.

\section{References}

Bois, B., Pieri, P., Van Leeuwen, C., Wald, L., Huard, F., Gaudillere, J. P., \& Saur, E. (2008). Using remotely sensed solar radiation data for reference evapotranspiration estimation at a daily time step. Agricultural and Forest Meteorology, 148(4), 619-630.

Bonta, J., Thurston, H., Warnemuende, E., \& Smith, D. R. (2005). Impacts of impervious surface on watershed hydrology: A review AU - shuster, W. D. Urban Water Journal, 2(4),263-275. doi:10.1080/15730620500386529

Charalambous, K., Bruggeman, A., \& Lange, M. (2012). Assessing the urban water balance: The urban water flow model and its application in cyprus. Water Science and Technology. Volume 66. Issue 3. doi:10.2166/wst.2012.188

Chatterjee, C., Jha, R., Lohani, A. K., Kumar, R., \& Singh, R. (2001). Runoff curve number estimation for a basin using remote sensing and GIS. Asian-Pacific Remote Sensing and GIS Journal, 14, 1-7.

Chhabra, N. (2011). Developing a life cycle assessment impact indicator for water resources in the built environment. Gainesville, Fla: University of Florida. Retrieved from http://purl.fcla.edu/fcla/etd/UFE0043484

Connor, R. (2015). The United Nations world water development report 2015: water for a sustainable world (Vol. 1). UNESCO Publishing.

Dile, Y. T., Karlberg, L., Srinivasan, R., \& Rockström, J. (2016). Investigation of the curve number method for surface runoff estimation in tropical regions. JAWRA Journal of the American Water Resources Association, 52(5), 1155-1169.

EPA. (n.d.). Water Budget Data Finder. Retrieved from https://www.epa.gov/watersense/water-budget-datafinder

Erban, L. E., Balogh, S. B., Campbell, D. E., \& Walker, H. A. (2018). An R Package for Open, Reproducible Analysis of Urban Water Systems, With Application to Chicago. Open Water Journal, 5(1), 3.

FSU. (2000). Florida Climate Center, Florida State University: Center for Ocean-Atmospheric Prediction Studies. Tallahassee, Florida. Retrieved from http://climatecenter.fsu.edu/climate-dataaccess-tools/climate-data-visualization

Gleick, P.H. and Palaniappan, M. (2010) Peak water: conceptual and practical limits to freshwater withdrawal and use. Proceedings of the National Academy of Sciences of the United States of America 107(25): 11155-11162.

Grimmond, C. S. B., \& Oke, T. R. (1986). Urban water balance: 2. Results from a suburb of Vancouver, British Columbia. Water Resources Research, 22(10), 1404-1412.

Harper, H. H., \& Baker, D. M. (2007). Evaluation of Current Storm water Design Criteria within the State of Florida. Environmental Research \& Design, Inc. Retrieved from 
https://www.sfwmd.gov/sites/default/files/documents /sw\%20treatment\%20report-final71907.pdf

Hawkins, R.H., Jiang, R., Woodward, D.E., Hjelmfelt, A.T., Van Mullem, J.A. (2002). Runoff Curve Number Method: Examination of the Initial Abstraction Ratio. Proceedings of the Second Federal Interagency Hydrologic Modeling Conference, Las Vegas, Nevada. 42 (3): 629-643. doi:10.1111/j.17521688.2006.tb04481

Houser, D. L., \& Pruess, H. (2009). The effects of construction on water quality: A case study of the culverting of Abram Creek. Environmental Monitoring and Assessment, 155(1), 431-442. doi:10.1007/s10661-008-0445-9

Johnston, R. H., \& Bush, P. W. (1988). Summary of the hydrology of the floridan aquifer system in florida and in parts of georgia, south carolina, and alabama. doi:10.3133/pp1403A Retrieved from USGS Publications Warehouse Retrieved from http://pubs.er.usgs.gov/publication/pp1403A

Kemper, K., \& Sadoff, C. (2006). On global water challenges. International Journal on Hydropower \& Dams, 13(2), 43-50.

Lu, J., Sun, G., McNulty, S. G., \& Amatya, D. M. (2005). A Comparison of Six Potential Evapotranspiration Methods for Regional Use in the Southeastern United States 1. JAWRA Journal of the American Water Resources Association, 41(3), 621-633.

Marella, R.L. (2004). Water withdrawals, use, discharge, and trends in Florida, 2000, U.S. Geological Survey Scientific Investigations Report 2004-5151, 138 p.

Mitchell, V. G., Cleugh, H. A., Grimmond, C. S. B., \& $\mathrm{Xu}, \mathrm{J}$. (2008). Linking urban water balance and energy balance models to analyse urban design options. Hydrological Processes: An International Journal, 22(16), 2891-2900.

Ponce, V. M., \& Hawkins, R. H. (1996). Runoff curve number: Has it reached maturity? Journal of hydrologic engineering, 1(1), 11-19.

Rain Master. (n.d.). Historic ET by Zip Code. Retrieved from http://www.rainmaster.com/historicET.aspx

Redfern, T. W., Macdonald, N., Kjeldsen, T. R., Miller, J. D., \& Reynard, N. (2016). Current understanding of hydrological processes on common urban surfaces. Progress in Physical Geography: Earth and Environment, 40(5), 699-713. https://doi.org/10.1177/0309133316652819
Ruby, E. (n.d.). How urbanization affects the water cycle. California Water \& Land Use Partnership. Retrieved from

https://www.coastal.ca.gov/nps/watercyclefacts.pdf

Salazar, L. F., Poveda, G., \& Climáticos, C. P. (2006). Validation of diverse evapotranspiration estimation methods using the long-term water balance in the Amazon River Basin. In Proceedings of (Vol. 8, pp. 24-28).

Silveira, L., Charbonnier, F., \& Genta, J. L. (2000). The antecedent soil moisture condition of the curve number procedure. Hydrological Sciences Journal, 45(1), 3-12.

Trajkovic, S., \& Kolakovic, S. (2009). Evaluation of reference evapotranspiration equations under humid conditions. Water Resources Management, 23(14), 3057.

United States Department of Agriculture (1986). Urban hydrology for small watersheds (pdf). Technical Release 55 (TR-55) (Second ed.). Natural Resources Conservation Service, Conservation Engineering Division.

UN WWDR, (2015). The UN World Water Development Report 2015, Water for a Sustainable World. UNESCO. Retrieved from http://www.unesco.org/new/en/naturalsciences/environment/water/wwap/wwdr/2015water-for-a-sustainable-world/

USEPA. (2012). An Overview of Water Quality in Ohio. Ohio 2012 Integrated Report. Section A. Retrieved from

https://epa.ohio.gov/portals/35/tmdl/2012IntReport/I R12SectionAfinal.pdf

USEPA. (2002). National Water Quality Inventory, 2000 Report. United States Environmental Protection Agency Office of Water Washington DC 20460. Retrieved from https://www.epa.gov/sites/production/files/201509/documents/2000_national_water_quality_inventor y_report_to_congress.pdf

USGS. (2016). How much water is there on, in, and above the Earth? U.S. Geological Survey. Retrieved from http://water.usgs.gov/edu/earthhowmuch.html

Wu, F., Zhan, J., \& Güneralp, İ. (2015). Present and future of urban water balance in the rapidly urbanizing Heihe River basin, northwest China. Ecological modelling, 318, 254-264. 
Table 1: Model variables and their relationship

\begin{tabular}{|c|c|c|}
\hline Process & Evaluation & Unit \\
\hline $\mathrm{AT}=$ Total Area & & sq. ft. \\
\hline AI = Impervious Area & & sq. ft. \\
\hline $\mathrm{AP}=$ Pervious Area & $\mathrm{AT}-\mathrm{AI}$ & sq. ft. \\
\hline Po $=$ Potable Water & cu. $\mathrm{ft}$ & cu. ft. \\
\hline $\mathrm{W}=\mathrm{W}$ aste water & $0.936 \times \mathrm{Po}$ & cu. ft. \\
\hline Rc $=$ Reclaimed water & & $\mathrm{ft}$. \\
\hline Pre = Precipitation & & $\mathrm{ft}$. \\
\hline PreE = Evapotranspiration from Precipitation & AP x $0.57 \times$ Pre & cu. ft. \\
\hline PreR = Runoff from Precipitation & A x Pre $x$ C Value & cu. ft. \\
\hline PreI = Infiltration from Precipitation & Pre - PreE - PreR & cu. ft. \\
\hline PreEr = Precipitation Evapotranspiration at Rention pond & PreR - PreRT - PreIr & cu. ft. \\
\hline PreIr = Precipitation Infiltration at Retention Pond & $0.5 \times$ PreR & cu. ft. \\
\hline PreET = Total Evapotranspitation from Precipitation & PreE + PreEr & cu. ft. \\
\hline PreIT $=$ Total Infiltration from Precipitation & PreI + PreIr & cu. ft. \\
\hline PreRT = Actual runoff from Precipitation & Function of PreR & cu. ft. \\
\hline Iw = Infiltration from supply chain & $0.064 \times$ Po & cu. ft. \\
\hline $\operatorname{Re}=$ Reclaimed water used in building for Irriragion & & cu. ft. \\
\hline ReE = Reclaimed Water Evapotranspiration & $0.18 \times \operatorname{Re}$ & cu. ft. \\
\hline ReR = Reclaimed Water Runoff & A x Re $\times$ C Value & cu. ft. \\
\hline ReI = Reclaimed Water Infiltration & Re - ReE - ReR & cu. ft. \\
\hline ReEr = Reclaimed Water Evapotranspiration at Retention pond & ReR- Rre - ReIr & cu. ft. \\
\hline ReIr =Reclaimed Water Infiltration at Retention Pond & $0.5 \times \operatorname{ReR}$ & cu. ft. \\
\hline Rre - Actual Runoff on Reclaimed water for irrigation on parcel & Function of ReR & cu. ft. \\
\hline Ere = Total Evapotranspiration from Reclaimed Irrigation & $\operatorname{ReE}+\operatorname{ReEr}$ & cu. ft. \\
\hline Ire $=$ Total Infiltration on Reclaimed Irrigation & ReI + Re Ir & cu. ft. \\
\hline IRRp = Potable water used for Irrigation on parcel (in) & & cu. ft. \\
\hline IRRpE = Potable Water Evapotranspiration & $0.18 \times$ IRRp & cu. ft. \\
\hline IRRpR = Potable Water Runoff & A x Po x C Value & cu. ft. \\
\hline IRRpI = Potable Water Infiltration & IRRp - IRRpE - IRRpR & cu. ft. \\
\hline IRRpEr = Potable Water Irrigation Evapotranspiration at Retention Pond & IRRp - IRRpRT - IRRpIr & cu. ft. \\
\hline IRRpIr = Potable Water Irrigation Infiltration at Retention Pond & $0.5 \times$ IRRpR & cu. ft. \\
\hline IRRpET = Total Evapotranspiration Potable Water Irrigation & IRRpE + IRRpEr & cu. ft. \\
\hline IRRpRT = Actual Potable water Irrigation runoff & Function of IRRpR & cu. ft. \\
\hline IRRpIT = Total Infiltration from Potable water for Irrigation & IRRpI + IRRpIr & cu. ft. \\
\hline Wirr = Waste water that goes to Irrigation (Out) & $0.112 \times \mathrm{W}$ & cu. ft. \\
\hline WirrE = Evapotranspiration on Waste water Irrigation & $0.18 \times$ Wirr & cu. ft. \\
\hline WirrR = Runoff on Waste water Irrigation & A x WirrR x C Value & cu. ft. \\
\hline WirrI = Infiltration on Waste water Irrigation & Wiir - WiirE - WirrR & cu. ft. \\
\hline WirrEr = Waste Water Irrigation Evapotranspiration at Retention Pond & WirrR - WirrRT - WirrIr & cu. ft. \\
\hline WirrIr $=$ Waste water Irrigation Infiltration at Retention Pond & $0.5 \times$ WirrR & cu. ft. \\
\hline WirrE = Total Evapotranspiration Waste water Irrigation & WirrE +WirrEr & cu. ft. \\
\hline WirrR - Actual Runoff Waste water irrigation & Function of WirrR & cu. ft. \\
\hline WirrI = Total Infiltration from Waste water for Irrigation & WirrI + WirrIr & cu. ft. \\
\hline IW = Injection Well Recharge & $0.72 \times \mathrm{W}$ & cu. ft. \\
\hline WL = Wetlands & $0.168 \times \mathrm{W}$ & cu. ft. \\
\hline WLE = Evapotranspiration at Wetlands & WL - WLR - WLI & cu. ft. \\
\hline WLR = Runoff at Wetlands & $0.015 \times \mathrm{WL}$ & cu. ft. \\
\hline WLI = Infiltration at Wetlands & $0.5 \times \mathrm{WL}$ & cu. ft. \\
\hline C value for Pre-Development & 0.006 & \\
\hline C value for Development & Function of \% Impervious & \\
\hline C value for Wetlands/Retention ponds & Function of runoff & \\
\hline
\end{tabular}

